\title{
BIOECONOMY-BASED FOOD INDUSTRY OF SERBIA: THE ROLE OF INTELLECTUAL CAPITAL
}

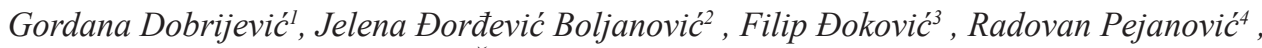
Goran Škatarićs , Ivana Damnjanović ${ }^{6}$

*Corresponding author E-mail: gdobrijevic@singidunum.ac.rs

\begin{abstract}
A R T I C L E I N F O
A B S T R A C T

Original Article

Received: 20 September 2018

The aim of this exploratory study was to determine most useful indicators of intellectual capital in Serbian food industry. The study investigated managers' perceptions of

Accepted: 24 January 2019

doi:10.5937/ekoPolj1901051D

UDC 005.96:[502.7+33(497.11) indicator usefulness and practical application. They were top and middle managers from 18 food organizations, committed to the bioeconomy. The survey items were divided into human, structural, and relational capital. A closed-ended questionnaire was used to collect data, later

Keywords:

knowledge-based bioeconomy, intellectual capital, intellectual analysed by SPSS 21 statistical software. The results have demonstrated that all indicators were seen as very important, with relational capital being the most useful of all.
\end{abstract} capital indicators

JEL: Q57, Q18, 034

(C) 2019 EA. All rights reserved.

\section{Introduction}

The majority of the EU regions/countries (98.6\%) feel pressured to include the bioeconomy related aspects in their research and development priorities and plans. At the same time, there are also regions in Europe that do not use their bioeconomy potential. The European Commission report (European Commission, 2017) demonstrates that the bioeconomy related research is a priority for most European countries and regions from 2014 to 2020. According to the Europe 2020 Strategy (passed in 2010), sustainable economy should be indispensable for contemporary organizations, as well as countries.

1 Gordana Dobrijević, PhD, Associate professor, Singidunum University, Danijelova no. 32, +381113094094, gdobrijevic@singidunum.ac.rs

2 Jelena Đorđević Boljanović, PhD, Associate professor, Singidunum University, Danijelova no. 32,+381113094094, jboljanovic@singidunum.ac.rs

3 Filip Đoković, PhD, Associate professor, Singidunum University, Železnička no. 5, +38114292611, fdjokovic@singidunum.ac.rs, ORCID ID (https://orcid.org/0000-0002-2342-9358)

4 Radovan Pejanović, PhD, Full professor, Agricultural Faculty, Dositeja Obradovica Square no. 8, 21000 Novi Sad, Phone: +381 216350 622, pejanovic@uns.rs

5 Goran Škatarić, PhD, Associate professor, Donja Gorica University, Donja Gorica bb, Donja Gorica bb, 81000 Podgorica, Phone: +382 20410 777, goran.skataric@udg.edu.me

6 Ivana Damnjanović, $\mathrm{PhD}$,Assistant professor, SingidunumUniversity, Železnička no. 5,+38114292611, idamnjanovic@singidunum.ac.rs, ORCID ID (https://orcid.org/0000-0001-7087-3147)

http://ea.bg.ac.rs 
Bioeconomy is a sustainable, eco-efficient transformation of renewable biological resources into food, energy and other industrial products (Schmid, Padel and Levidov, 2012). The driving factors in bioeconomy may be political - realising existing or newly defined objectives in a country, or economic - stimulating existing economic performance and/or generating new market forces, such as realisation of environmental protection objectives (reducing waste, reducing greenhouse gas emissions, and improvement of environmental quality) (European Commission, 2015). In a more detailed analysis of the factors influencing this type of economy, the OECD classified all the factors into external and institutional i.e. social ones (OECD, 2009). The external factors include: an increase in global population, which is expected to reach 8.3 billion in 2030; demographic changes, in terms of an increasingly ageing, but also more educated population; energy consumption and climate change; increasing demand for agricultural products, rising food prices and water scarcity; increase in healthcare costs; development of technologies, particularly those relevant to the bioeconomy - informatics (IT) and nanotechnology. Analysing these trends, the OECD's strategy points out that the influence of these factors on bioeconomy is different across different sectors. For example, population growth will have an impact on primary production, demographic changes will have an impact on health biotechnology, while the climate change will affect industrial processes. On the other hand, according to the OECD, the most important drivers for the development of bioeconomy are three institutional and one social: public research funding, legal regulations, intellectual property and public acceptance.

\section{Materials and methods}

The European Commission (2012a) defines bioeconomy as the "production of renewable biological resources and the conversion of these resources and waste streams into value - added products, such as food, feed, bio based products, and bio energy." It includes agriculture, forestry, fisheries, food, pulp and paper production sectors, and parts of chemical, biotechnological and energy industries. It is related to different sciences, including life sciences, ecology, biotechnology, agronomy, and ICT (European Commission, 2012b). Bioeconomy provided jobs for around 18.6 million people in the EU in 2014, or 8.5\% of total European work force. Agriculture, and food, beverage and tobacco sectors account for three quarters of that number (Ronzon et al., 2017). The main elements of bioeconomy are: food production and processing, agri-environmental products and services, value-added food and health products, and energy and bio-processing (Socaciu, 2014).

Literature review shows different, sometimes opposing, views regarding bioeconomy and green economy. For example, according to Socaciu (2014), green economy is part of an overall bioeconomy concept. On the other hand, D'Amato et al. (2017) analysed bibliometric data from almost 2,000 articles published around the world during the last thirty years. They reached the conclusion that green economy comprises concepts from bioeconomy, such as bio-efficiency. While green economy deals with all ecological processes, and is more focused on certain features at local level (such as eco-tourism), bioeconomy is directed more towards resources, biosecurity and rural policies (Socaciu, 2014). 
Unlike the traditional agricultural systems, the bioeconomy-oriented systems concentrate on incorporating environment, natural resources, food and agriculture, energy and industrial development (Socaciu, 2014). Agriculture is the main source of local employment in many countries. Closely connected to agriculture, bioeconomy creates food and energy by use of sustainable biological resources, thus facilitating resource efficiency and reducing the carbon footprint (European Investment Bank, 2017). Various adverse factors that influence global economy, such as limited access to energy resources, population growth, and periodic financial crises have brought about the change of the global agricultural framework. Agriculture has to adjust to the new economic and environmental challenges. Food safety and security have become the cornerstones of the European agricultural model (Drăgoi et al., 2018), while food quality and safety have incorporated new values for companies and consumers (Pop, Dracea, and Vlădulescu, 2018). Food security is an extensive issue, which has various economic, social and environmental aspects. Food and feed are important parts of bioeconomy (Ronzon et al., 2017).

Bioeconomy requires intensifying research and development activities; bringing together professionals from various fields, who are willing and motivated to share their knowledge and to convert tacit forms of knowledge into explicit, accessible to all; developing an environment that will foster creativity and innovation, providing new ideas and solutions; freely accessible, easy-to-search knowledge bases. Only this can ensure a free flow of knowledge within an organisation and using all available resources (Đorđević Boljanović, 2009). It is worth mentioning the launch of the Bioeconomy Knowledge Centre (n.d.), under the auspices of the European Commission, which provides open access to the knowledge on the methods of sustainable production of renewable resources and their transformation into new products. Consider all that, also can be said that power of humanmachine collaboration is need in industry growth (Bolton et al., 2018).

To fully understand the significance of knowledge in bioeconomy, it is important to define the so-called environmental knowledge. According to Fryxell (2003), this kind of knowledge is defined as general knowledge of facts, concepts and relationships concerning the natural environment and its major ecosystems, i.e. the knowledge that people have about the environment, key environmental aspects and impacts, and about collective responsibilities for sustainable development. The definition itself conveys the impact that the management of this kind of knowledge has on sustainable development of organisations, especially those focused on bioeconomy. Such organisations strive to manage this knowledge in order to make it useful for their business activities and to address the four key current challenges that have emerged both in theory and in practice (Beljić at al., 2013):

- inconsistency between environmental knowledge about management of raw materials, energy efficiency, and waste;

- failure to identify and analyse important environmental features related to raw materials, energy and waste management; 
- lack of empowerment, which prevents employees from taking relevant environmental protection actions, using their environmental knowledge and integrating their individual knowledge, plans, experience and goals into organisational structures;

- lack of ability of an organisation to make external contacts, acquire and adopt knowledge from external stakeholders and to properly integrate it into internal knowledge.

Therefore, an organisation that is committed to sustainable development and the bioeconomy-based business needs to focus on its knowledge resources and its intellectual capital (IC). IC is related to a company's whole operations (Starovic and Marr, 2006). If sustainability is one of the fundamental postulates of bioeconomy, then intellectual capital of an organisation is indeed one of the key indicators showing the extent of business sustainability of an organisation, i.e. to what extent an intellectual capital investment will provide not only its temporary survival in the environment, but also the continuation of its effective business performance (Bose and Thomas, 2007). This involves striving for sustainable food production that will be based on regeneration of natural resources and the assimilation capacity of the environment (Szücs, Vanó, Korsós-Schlesser, 2017).

\section{Intellectual Capital}

The knowledge economy has moved its attention from tangible to intangible assets (Bramhandkar, Erickson, and Applebee, 2007). The intangibles are also becoming increasingly important in business appraisal (Bischoff, Vladova, and Jeschke, 2013). They clarify the gap between a company's book and market value (Sveiby, 1997). Intellectual capital, also called intangible assets or knowledge assets, are assets that do not have a material or financial manifestation (OECD, 2011). Among the most widely accepted definitions are "Intangible assets are those that have no physical existence but are still of value to the company" (Edvinsson and Malone, 1997, p. 22), and "Intellectual capital is intellectual material - knowledge, information, intellectual property, experience - that can be put to create wealth - collective brainpower" (Stewart, 1998, p. XI).

Intellectual capital is usually divided into human, structural, and relational capital (Starovic and Marr, 2006). Human capital consists of the competence, knowledge, and creativity of all employees of an organization. Structural or internal capital integrates procedures, patents, models, and databases belonging to the organization, independent of individuals. Relational capital, includes the relationships with customers and partners, marketing channels, brands, and the organization's reputation (Sveiby, 2001; Feleagă, L., Feleagă, N., Dragomir, and Râbu, 2013).

All these elements are closely related and their synthesis leads to creation of new values for the company. Their interrelations are singular for each context, industry or organization (Kozera, 2011; López López, \& Salazar - Elena, 2017). 
There is now consensus on importance of intangibles in creating value, and many studies (e.g. Zeghal, and Maaloul, 2010; Vishnu and Gupta, 2014, Urbanek, 2016, Sharabati, Naji Jawad, Bontis, 2010) have found a significant positive impact of intellectual capital on organizational performance. However, there are different approaches to measuring intellectual capital. This area is still evolving, so many of these approaches have limitations. Companies need to understand how these intangible assets are developed, so that they could allocate their resources more effectively, and eventually create more value (Starovic and Marr, 2006).

As reported by Sveiby (2010), "No one method can fulfil all purposes." Organizations should choose a method according to "purpose, situation and audience" (Sveiby, 2010, p. 4). Therefore, it is no wander there are quite a few different methods for measuring intellectual capital. For example, Kaplan and Norton(2004) based their Balanced Scorecard on causal relationships between four measurables (financial, customer, internal processes, and learning and growth) and objectives within "strategy maps". Similarly, the Skandia Navigator (Edvinsson and Malone, 1997) analyses financial, process, human, customer, and innovation perspectives, using different indicators to measure them, human capital being the most important element of the Navigator. Celemi's Intangible Assets Monitor combines three categories, namely people (competence), customers (external structure), and organization (internal structure), with three main areas of growth, efficiency, and stability (Starovic and Marr, 2006). In their study in Canada, Miller, DuPont, Fera, Jeffrey, Mahon, Payer, and Starr (1999) also divided intellectual capital in human, structural, and customer capital. They found that human and customer capital indicators were preferred above structural capital indicators.

There are several important national programmes and strategies related to green and bioeconomy in Serbia, e.g. National Strategy on Sustainable Use of Natural Resources and Environment, National Sustainable Development Strategy, and National Environmental Protection Programme. Many companies in Serbia are dedicated to green economy and bioeconomy (UNDP / UNEP, 2012). Still, to the authors' best knowledge, only few studies have addressed intellectual capital, or specifically, intellectual capital in food industry in Serbia (Kontić and Čabrilo, 2009; Komnenic, Tomic, D. and Tomic, G., 2010; Djekic, I., Dimitrijevic, B. and Tomic, N., 2017).

Komnenic, Tomic, D. and Tomic, G. (2010) established a positive relationship between the IC and organizational performance in the agri-food sector of Vojvodina (Serbian northern province). Djekic, Dimitrijevic, and Tomic (2017) found that the most valued IC indicators in Serbian fruit industry are customer satisfaction and loyalty (indicators of relational capital), while the study of Kontić and Čabrilo (2009) showed that human indicators are more important than relational and structural IC indicators.

The main objective of our exploratory study is to identify the indicators of intellectual capital that are relevant and applicable in Serbia. These indicators would in turn help Serbian enterprises manage their intellectual capital, which is of paramount importance for improving organizational performance levels. 
The paper is organized as follows: It begins with the literature review, which introduces and defines bioeconomy. Then intellectual capital, its structure and measurement are presented. The methodological section shows the logic behind using the particular methods in this study was explained, as well as the data collection and analysis. Then the results are analysed and compared to previous research. The conclusions are discussed in the final section.

\section{Methodology}

In order to examine the importance of managing intellectual capital in food industry organizations, we focused on managers' perception of the value and usability of IC indicators. Two main research questions were explored:

1. What IC indicators do managers in food industry regard as useful?

2. What IC indicators do managers use in their activities?

The survey was conducted by email from January to March 2018, with the response rate of $44.2 \%$ ). We focused on food industry organizations which clearly show (publicly promote on their website) their commitment to bioeconomy, such as solving problems of biodegradable waste from their own production process, using waste to produce energy, clean production, etc. All of them belong to large and medium enterprises. The respondents (61 in total) were top and middle managers from 18 companies belonging to different areas of food industry in Serbia, such as meat industry, fruit and vegetable juices industry, dairy industry, etc. (Statistical Office of the Republic of Serbia, n.d.). The same research sample was used in a wider study, with a different research focus and modified research questions (Djordjevic-Boljanovic, Dobrijevic, Cerovic, Alcakovic, Djokovic, 2018).

We used a modified form of the survey used in the research by Miller, DuPont, Fera, Jeffrey, Mahon, Payer, and Starr (1999), conducted in different industrial sectors in Canada. The original survey was based on IFAC (1998), Sveiby (1997), and Edvinsson and Malone (1997). The definitions of all relevant terms were provided at the beginning of the survey: intellectual capital, human capital, structural capital, relational capital.

Statistical analysis was carried out using SPSS Statistics 21. The internal consistency of the instruments used was checked using Cronbach's alpha coefficient (Table 1). The items showed relatively high internal consistency, over 0.8 , including the overall (0.889), as well as the separate IC indicators, all over 0.8 .

Table 1. Cronbach's alpha coefficient

\begin{tabular}{|l|l|l|}
\hline Measured construct & Number of items & Cronbach's alpha coefficient \\
\hline Indicator usefulness (all) & 33 & 0.889 \\
\hline Human indicators & 9 & 0.851 \\
\hline Structural indicators & 13 & 0.827 \\
\hline Relational indicators & 11 & 0.847 \\
\hline
\end{tabular}




\section{Results and Discussion}

High scores in Table 2 indicate that managers value the importance of all IC indicators. Relational indicators (e.g. customer loyalty, customer satisfaction, number of supplier/ customer networks) are considered most useful of all, while structural indicators (such as number of software licenses, number of multifunctional product teams, and average length of time for product design) are considered least useful. This is not consistent with the results of Kontić and Čabrilo (2009), and Miller, DuPont, Fera, Jeffrey, Mahon, Payer, and Starr (1999), which found that human capital indicators were perceived as the most useful of all. The reason for high perceived usefulness of relational capital indicators could be that, since bioeconomy is relatively a new field, companies try to acquire sustainable competitive advantage through relationships with customers and other stakeholders (Djordjevic-Boljanovic, Dobrijevic, Cerovic, Alcakovic, Djokovic, 2018).

Table 2. Perception of overall usefulness of IC indicators

\begin{tabular}{|c|l|l|l|l|l|}
\hline & N & Min & Max & M & SD \\
\hline IC indicators (all) & 61 & 3.1 & 4.97 & 4.12 & 0.39 \\
\hline Human indicators usefulness & 61 & 2.89 & 5 & 4.16 & 0.45 \\
\hline Structural indicators usefulness & 61 & 2.62 & 4.92 & 3.88 & 0.48 \\
\hline Relational indicators usefulness & 61 & 3.09 & 5 & 4.33 & 0.47 \\
\hline
\end{tabular}

Note. $\mathrm{n}$ - sample size, Min - minimum, Max - maximum, $M$ - Mean, $S D$ - standard deviation

Amongst individual human capital indicators, employee motivation, employee satisfaction, and IT literacy of staff are seen as the most important. They are also most used indicators. Employee motivation is the most important indicator of all used in our study (mean 4.79). In knowledge economy, employee motivation and satisfaction are crucial in gaining competitive edge, because motivated and satisfied employees lead to more satisfied and loyal customers.

In general, relational capital indicators are perceived as most important of all IC indicators, most of all market share, customer loyalty, and customer satisfaction, while ratio of customers to employees and number of alliances or partnerships are considered least important. On the other hand, the number of supplier/customer networks is used most frequently of all relational capital indicators. Relational capital focuses on the role of social interactions and benefit of connections (Still, Huhtamäki, \& Russell, 2013).

Regarding the question of how the managers would use each of the human, structural, and relational capital, the results show considerable differences between the three groups of indicators. More than $57 \%$ stated they would use all three groups of IC indicators to increase shareholder value. Naturally, almost all managers $(96.7 \%)$ would use human capital indicators to manage human resources (Table 3). Moreover, two thirds of participants would use human capital indicators to improve operational efficiency. 
Table 3. Preferred indicator use

\begin{tabular}{|c|c|c|c|c|}
\hline Use indicator to & $\mathbf{N}$ & Human capital & Structural capital & Relational capital \\
\hline Manage human resources & 61 & $96.70 \%$ & $24.60 \%$ & $23.00 \%$ \\
\hline Market product & 61 & $31.10 \%$ & $50.80 \%$ & $68.90 \%$ \\
\hline Secure funding/capital & 61 & $31.10 \%$ & $70.50 \%$ & $52.50 \%$ \\
\hline Gain competitive edge & 61 & $47.50 \%$ & $57.40 \%$ & $78.70 \%$ \\
\hline Increase shareholder value & 61 & $57.40 \%$ & $68.90 \%$ & $63.90 \%$ \\
\hline Improve quality of product & 61 & $47.50 \%$ & $62.30 \%$ & $59.00 \%$ \\
\hline Improve operational efficiency & 61 & $65.60 \%$ & $68.90 \%$ & $32.80 \%$ \\
\hline Allocate resources & 61 & $50.80 \%$ & $70.50 \%$ & $32.80 \%$ \\
\hline Facilitate budget planning & 61 & $55.70 \%$ & $68.90 \%$ & $42.60 \%$ \\
\hline Influence government policy & 61 & $33.30 \%$ & $50.00 \%$ & $60.00 \%$ \\
\hline
\end{tabular}

Note. $\mathrm{n}$ - sample size

The results have shown that the majority of everyday managerial activities would require structural capital indicators. This is conflicting with answers to previous questions (Table 2), which showed that structural capital indicators are the least useful of all IC indicators. The reason for this could be that structural capital elements (such as patents, licenses, and data bases) are easier to assess and evaluate than human capital, and is owned by the company. Contrarily, employees only work for the company, and their skills and knowledge are not owned by the company. Structural capital is generally perceived to be a support for human capital (Djordjevic-Boljanovic, Dobrijevic, Cerovic, Alcakovic, Djokovic (2018).

\section{Conclusions}

The research objective of this paper was to determine the indicators of intellectual capital that are applicable and useful in bioeconomy-based food companies in Serbia.

The managers perceived intellectual capital indicators as quite useful (overall higher than 4.1) in most cases. Our results have demonstrated that relational capital indicators are seen as the most useful. Relational capital is the value based on maintaining good relationships with organization's customers and partners. It means that the majority of managers who participated in this study value the connections and networking with organization's stakeholders.

Unexpectedly, structural capital indicators would be used in nearly all managerial activities, even though these indicators were perceived as least useful. The reason for this could be that structural capital is usually seen as some sort of support for human capital, since it is visible and easily quantifiable.

There are several limitations to this research. Only the companies in food industry committed to bioeconomy were included in the survey. The results would probably be different if compared to other industries or sectors. The research sample was too small for generalizing results for the whole industry. This research could be useful in understanding and application of IC indicators in the process of managing intellectual 
capital in bioeconomy-based food organizations in Serbia. Future research could spread across other industrial sectors in Serbia, with a larger sample.

\section{Conflict of interests}

The authors declare no conflict of interest.

\section{References}

1. Beljić, M., Panapanaan, V., Linnanen, L., \& Uotila, T. (2013). Environmental knowledge management of Finnish food and drink companies in eco-efficiency and waste management. Interdisciplinary Journal of Information, Knowledge, and Management, 8, 99-119.

2. Bioeconomy Knowledge Centre (n.d.), available on https://biobs.jrc.ec.europa. eu, accessed March 20, 2018

3. Bischoff, S., Vladova, G., Jeschke, S. (2013) Measuring Intellectual Capital. In Automation, Communication and Cybernetics in Science and Engineering 2011/2012. Jeschke, S., Isenhardt, I., Hees, F., Henning, K. (Eds.) 2013, XXVI. ISBN 978-3-642-33389-7. Springer-Verlag Berlin Heiderberg.

4. Bolton, Charlynne, Veronika Machová, Maria Kovacova, and Katarina Valaskova (2018). The Power of Human-Machine Collaboration: Artificial Intelligence, Business Automation, and the Smart Economy, Economics, Management, and Financial Markets 13(4): 51-56.

5. Bose, S., Thomas, K. (2007) Valuation of intellectual capital in knowledgebased firms The need for new methods in a changing economic paradigm, Management Decision, Vol. 45 Iss 9 pp. 1484 - 1496, available from http:// dx.doi.org/10.1108/00251740710828726, Emerald Insight

6. Bramhandkar, A., Erickson, S. and Applebee, I. (2007) Intellectual Capital and Organizational Performance: An Empirical Study of the Pharmaceutical Industry. Electronic Journal of Knowledge Management, 5, 357-362.

7. D'Amato D, Droste N, Allen B, Kettunen M, Lähtinen K, Korhonen J, Leskinen P, Matthies BD, Toppinen A, (2017). Green, circular, bio economy: A comparative analysis of sustainability avenues. Journal of Cleaner Production, doi: 10.1016/j. jclepro.2017.09.053.

8. Djekic, I., Dimitrijevic, B. and Tomic, N. (2017) Quality Dimensions of Intellectual Capital in Serbian Fruit Industry. Engineering Management Journal, 29 (3), 154-164, DOI: 10.1080/10429247.2017.1339582. Available from http:// dx.doi.org/10.1080/10429247.2017.1339582. Accessed March 22, 2018.

9. Djordjevic-Boljanovic, J. Dobrijevic, G., Cerovic, S., Alcakovic, S., Djokovic, F. (2018) Knowledge-Based Bioeconomy: the Use of Intellectual Capital in Food Industry of Serbia. Amfiteatru Economic 20 (49):717-731 
10. Drăgoi, M.C., Andrei, J.V., Mieilă, M., Panait, M., Dobrotă, C.E. and Lădaru, R.G., (2018). Food Safety and Security in Romania - An Econometric Analysis in the Context of National Agricultural Paradigm Transformation. Amfiteatru Economic, 20(47), pp. 134-150.

11. Đorđević Boljanović J. (2009) Menadžment znanja (In Serbian). Data Status, Belgrade.

12. Edvinsson, L. \& Malone, M. (1997). Intellectual Capital: Realizing Your Company's True Value by Finding Its Hidden Brainpower. Harper Business, New York.

13. European Commission (2012a) Bioeconomy Strategy and Action Plan "Innovating for Sustainable Growth: A Bioeconomy for Europe”. Available from https://wbcrti.info/object/event/11271/attach/05 Bio economy for Europe.pdf accessed September 4, 2018.

14. European Commission (2012b) Communication from the Commission to the European Parliament, the Council, the European Economic and Social Committee and the Committee of the Regions Innovating for Sustainable Growth: A Bioeconomy for Europe. Available from http://ec.europa.eu/research/ bioeconomy/pdf/official-strategy en.pdf, accessed March 7, 2018.

15. European Commission (2015) Results of the JCR - SCAR Bioeconomy Survey, author: J.W.A. Langeveld, accessed at https:/www.scar-swg-sbgb.eu/lw resource/datapool/ items/item_24/survey bioeconomy report1501 full text. pdf, downloaded on 30.1.2018.

16. European Commission (2017) Bioeconomy development in EU regions Mapping of EU Member States' / regions' Research and Innovation plans \& Strategies for Smart Specialisation (RIS3) on Bioeconomy, Final Report - February 2017, written by Silke Haarich.

17. European Investment Bank (2017) Agriculture and bioeconomy: Unlocking production potential in a sustainable and resource-efficient way. Available at http://www.eib.org/infocentre/publications/all/agriculture-and-bioeconomy.htm. Accessed March 7, 2018

18. Feleagă, L., Feleagă, N., Dragomir, V. and Râbu, L. (2013) European evidence on intellectual capital: Linking methodologies with firm disclosures. Acta Oeconomica, 63 (2), 139-156

19. Fryxell, G., \& Lo, C. W. H. (2003). The influence of environmental knowledge and values on managerial behaviors on behalf of the environment: An empirical examination of managers in China. Journal of Business Ethics, 46(1), 45-69.

20. Goods and Farmer Perspective, Bio-based and Applied Economics 1(1): pp. 4763., ISSN 2280-6172 (online), Firenze University Press, prema DG Research (2006) FP7 Theme 2: food, agriculture, fisheries and biotechnology (FAFB) 
21. International Federation of Accountants (IFAC), (1998). The Measurement and Management of Intellectual Capital: An Introduction. Study 7, IFAC, New York.

22. Kaplan, R., Norton, D. (2004) Strategy Maps: Converting Intangible Assets into Tangible Outcomes. Harvard: Harvard Business School Publishing Corporation.

23. Komnenic, B, Tomic, D. and Tomic, G. (2010) Measuring Efficiency of Intellectual Capital In Agriculture Sector of Vojvodina. APSTRACT (Applied Studies in Agribusiness and Commerce). 4(3-4), pp 25/31

24. Kontić, Lj. and Čabrilo, S. (2009) A Strategic Model for Measuring Intellectual Capital In Serbian Industrial Enterprises. Economic Annals 14(183), pp. 89-117

25. Kozera, M. (2011) Intellectual capital in agriculture - measurement and determinants. Acta Scientiarum Polonorum Oeconomia 10(3), pp. 83-95

26. LópezLópez, A. \& Salazar - Elena,J. C. (2017) The Role of Intellectual Capital Management on Innovation Process: Does One Size Fit All? UAM - Accenture Working Papers ISSN: 2172-8143. Working Paper \# 2017/29.

27. Miller, M., DuPont, B.D., Fera, V., Jeffrey, R., Mahon, B., Payer, B.M. and Starr, A.(1999) Measuring And Reporting Intellectual Capital From a Diverse Canadian Industry Perspective: Experiences, Issues and Prospects. OECD Symposium, Amsterdam June 9-11, 1999.

28. OECD (2009) The Bioeconomy to 2030, Designing a policy agenda, accessed at http://www.oecd.org/futures/long-termtechnologicalsocietalchallenges/ thebioeconomyto2030designingapolicyagenda.htm, downloaded on 30.1.2018

29. OECD (2011) A new OECD project New sources of growth: intangible assets, available at https://www.oecd.org/sti/inno/46349020.pdf. Accessed February 27, 2018.

30. Pop, S.Z., Dracea, R. and Vlădulescu, C. (2018). Comparative Study of Certification Schemes for Food Safety Management Systems in the European Union Context. Amfiteatru Economic, 20(47), pp. 9-29.

31. Ronzon, T., Lusser, M., Klinkenberg, M. (ed.), Landa, L., Sanchez Lopez, J. (ed.), M'Barek, R., Hadjamu, G. (ed.), Belward, A., (ed.), Camia, A., (ed.), Giuntoli, J., Cristobal, J., Parisi, C., Ferrari, E., Marelli, L., Torres de Matos, C., Gomez Barbero, M., Rodriguez Cerezo, E. (2017). Bioeconomy Report 2016. JRC Scientific and Policy Report. EUR 28468 EN

32. Schmid, O., Padel, S., Levidow, L. (2012). The Bio-Economy Concept and Knowledge Base in a Public Goods and Farmer Perspective. Bio-based and Applied Economics 1(1), pp. 47-63.

33. Sharabati, A., Naji Jawad, S., Bontis, N. (2010). Intellectual capital and business performance in the pharmaceutical sector of Jordan. Management decision, 48(1), pp. 105-131 DOI 10.1108/00251741011014481

34. Socaciu, C. (2014). Bioeconomy and green economy: European strategies, action plans and impact on life quality, Bulletin UASVM Food Science and Technology, 71(1), pp. 1-10. 
35. Starovic, D. and Marr, B. (2006) Understanding corporate value: Managing and reporting intellectual capital. London: Chartered Institute of Management Accountants. Available from http://www.cimaglobal.com/Documents/ ImportedDocuments/intellectualcapital.pdf, accessed February 27, 2018

36. Statistical Office of the Republic of Serbia, available from http://www.stat.gov.rs/ WebSite/Default.aspx, accessed March 21, 2018.

37. Stewart, T.A. (1998). Intellectual Capital - the new Wealth of Organizations, Nicolas Brealey Publishing, London.

38. Still, K., Huhtamäki, J. \& Russell, M. (2013). Relational Capital and Social Capital: One or two Fields of Research?. Proceedings of the 10th International Conference on Intellectual Capital, Knowledge Management and Organisational Learning, The George Washington University, Washington, DC, USA, 24-25 October 2013, pp. 420-428.

39. Sveiby, K.E. (1997). The New Organizational Wealth: Managing and Measuring Knowledge-Based Assets. Berrett-Koehler Publishers, Inc., San Francisco.

40. Sveiby, K-E. (2001) A knowledge-based theory of the firm to guide in strategy formulation. Journal of Intellectual Capital, 2(4), pp. 344-358

41. Sveiby, K-E. (2010) Methods for measuring intangible assets, January2001, updated 27 April 2010. Available at http://www.sveiby.com/files/pdf/ intangiblemethods.pdf. Accessed February 27, 2018.

42. Szücs, C., Vanó, G., Korsós-Schlesser, F. (2017) Agricultural and Food Production in Hungary: On the Road to Sustainability, Visegrad Journal on Bioeconomy and Sustainable Development, 6(2), pp. 59-63, ISSN (Online) 1339-3367, DOI DOI: $\underline{\text { https://doi.org/10.1515/vjbsd-2017-0010 }}$

43. UNDP / UNEP (2012). Study on Achievements and Perspectives towards a Green Economy and Sustainable Growth in Serbia. Available on https:// sustainabledevelopment.un.org/content/documents/984serbia.pdf, accessed March 2, 2018.

44. Urbanek G. (2016)“The links between the Intellectual Capital Efficiency Ratio (ICER) and the performance of Polish Listed companies from the food industry sector. The Electronic Journal of Knowledge Management, 14(4), pp. 220-230, available online at www.ejkm.com. Accessed February 28, 2018

45. Vishnu, S. And Gupta, K. (2014) Intellectual Capital and Performance of Pharmaceutical Firms in India. Journal of Intellectual Capital, 15, 83-99. https:// doi.org/10.1108/JIC-04-2013-0049

46. Zeghal, D. andMaaloul, A. (2010) Analysing Value Added as an Indicator of Intellectual Capital and its Consequences on Company. Performance. Journal of Intellectual Capital, 11, pp. 39-60. https://doi.org/10.1108/14691931011013325 